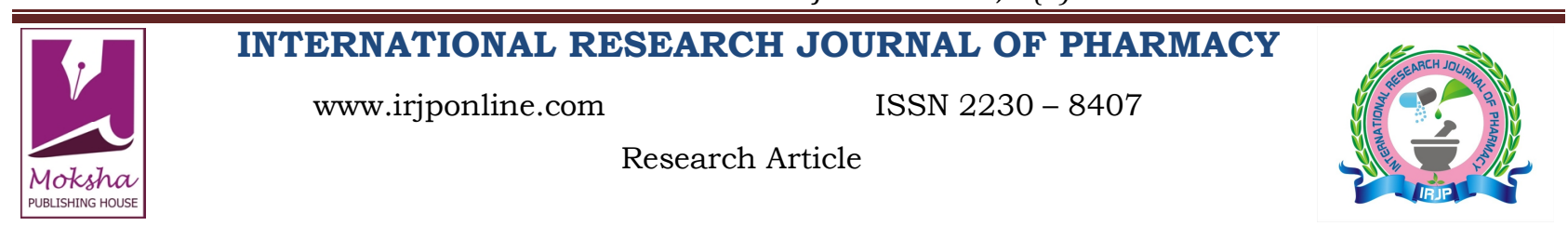

\title{
QUANTIFICATION OF PRIMARY AND SECONDARY METABOLITES FROM LEAVES AND STEM BARK OF COCHLOSPERMUM RELIGIOSUM (L) ALSTON
}

Sasikala A*, Linga Rao M and Savithramma N

Department of Botany, S.V. University, Tirupati, A.P, India

*Corresponding Author Email: asasikala.j1@gmail.com

Article Received on: 20/07/13 Revised on: 21/07/13 Approved for publication: 18/08/13

DOI: 10.7897/2230-8407.04845

IRJP is an official publication of Moksha Publishing House. Website: www.mokshaph.com

(C) All rights reserved.

\section{ABSTRACT}

Phytochemical constituents are responsible for medicinal activity of plant species. Hence the present study quantification of primary and secondary metabolites from leaves and stem bark of Cochlospermum religiosum was carried out. The results showed that the leaf was rich in chlorophylls followed by lipids, proteins and carbohydrates whereas in stem bark highest amount found in chlorophylls followed by carbohydrates, proteins and lipids of primary metabolites. Cochlospermum religiosum leaf was rich in phenols followed by alkaloids, flavonoids and tannins whereas in stem bark highest amount found in phenols followed by flavonoids, alkaloids and tannins of secondary metabolites. The results suggest that phytochemical properties for curing various ailments and possess potential antioxidant, anti-inflammatory, antimicrobial and leads to the isolation of new and novel compounds.

Keywords: Cochlospermum religious, primary metabolites, secondary metabolites, leaves, stem bark, Phenols.

\section{INTRODUCTION}

Cochlospermum religiosum (L) Alston is a sparsely branched small tree, belonging to the family Cochlospermaceae. It is commonly called as Yellow Silk Cotton, Buttercup Tree and Torchwood Tree because of flowers are large, bright golden yellow and seeds covered with silky hairs. Cochlospermum religiosum stem bark and root powder is traditionally used for fertility and ash of fruit mixed with coconut is used for the treatment of scabies ${ }^{1}$. The gum of Cochlospermum religiosum is also found to be an ingredient of unani medicine Qurs-e-Sartaan Kafoori which is used for Styptic, Antipyretic, Phthisis, Tuberculosis, Hectic fever and Qurs-eSuzak Cicatrizant, Diuretic, Gonorrhea. These formulations were found to possess good antibacterial and antifungal activity $^{2}$. Sasikala and Savithramma ${ }^{3}$ studied the antimicrobial activity of biological synthesis of silver nanoparticles from leaves of Cochlospermum religiosum and also studied the preliminary phytochemical screening and found flavonoids, steroids, tannins, glycosides, alkaloids, phenols etc. in different solvents ${ }^{4}$. Plant synthesizes a wide variety of chemical compounds which can be sorted by their chemical class, biosynthetic origin and functional groups into primary and secondary metabolites. Primary metabolites directly involved in growth and development of plants. These are widely distributed in nature, occurring in one form or another in virtually all organisms. They are like chlorophyll, amino acids, nucleotides and carbohydrates have a key role in metabolic processes such as photosynthesis, respiration and nutrient assimilation. They are used as industrial raw material and food additives. Many plants such as Nerium indicum ${ }^{5}$, Gloriosa superb ${ }^{6}$, Ricinus communis and Euphorbia hitra? Pongamia pinnata ${ }^{8}$ and Moringa oleifera ${ }^{9}$ have been evaluated for their composition of primary metabolites. Secondary metabolites are the basic source for the establishment of several pharmaceutical industries. The constituents present in the plants play a significant role in the identification of crude drugs. Phytochemical screening is very important in identifying new sources of therapeutically and industrially important compounds like alkaloids, flavonoids, phenolic compounds, steroids etc ${ }^{10}$. Previously the crude drugs were identified by comparison only with the standard descriptions available, but recently due to advancement in the field of pharmacognosy various techniques have been following for the standardization of crude drugs. Several plants are studied for quantification of secondary metabolites in Svensonia hyderobadensis ${ }^{11}$, Boswellia ovalifoliolata $^{12}$, Shorea tumbuggaia ${ }^{13}$, Jatropha ${ }^{14}$, Clerodendron colebrookianum and Zingiber cassumunar ${ }^{15}$ and Spondias mombin ${ }^{16}$. In the present study quantification estimation of primary and secondary metabolites from leaf and stembark of Cochlospermum religiosum.

\section{MATERIALS AND METHODS}

\section{Collection of plant material}

Fresh leaves and stembark of Cochlospermum religiosum was collected from the Tirumala hills and different locations of Chittoor district, Andhra Pradesh, India during the month of December, 2012. The leaves and stem bark were washed thoroughly 2-3 times with running tap water and then air dried under shade after complete shade drying the plant material was used for phytochemical analysis.

\section{Quantification of Primary and Secondary Metabolites}

Quantification of primary and secondary metabolites were carried out by the following methods of proteins ${ }^{17}$, carbohydrates $^{18}$, lipids ${ }^{19}$ and chlorophylls ${ }^{20}$; phenols and tannins ${ }^{21}$, flavonoids ${ }^{22}$ and alkaloids ${ }^{23}$.

\section{RESULTS AND DISCUSSION}

\section{Quantification of Primary metabolites}

In the present study, quantification of primary metabolites in leaves and bark of Cochlospermum religiosum has been under taken, the results are present in Table 1. The total lipids of $0.2 \pm 0.057 \mathrm{mg} / \mathrm{gdwt}$ are found in leaves and $0.04 \pm 0.00$ $\mathrm{mg} /$ gdwt in bark. The higher amount of plant lipid can be used as essential oils, spice oleoresins and natural food colors, with a strong foundation in research and development. Plant lipids are products that work with diverse requirements, as culinary, medicinal and cosmetics ${ }^{24}$. The leaves showed $0.075 \pm 0.03 \mathrm{mg} / \mathrm{gdwt}$ of carbohydrates and bark $0.110 \pm$ $0.02 \mathrm{mg} /$ gdwt. Starch is biodegradable and renewable in nature, they are increasingly being considered as an eco- 
friendly alternative to the use of synthetic additives in many other products, including plastics, detergents, pharmaceutical tablets, pesticides, cosmetics and even oil-drilling fluids ${ }^{25}$. Plant sugars can be used as artificial sweeteners and they can even help diabetes by supporting the body in its rebuilding ${ }^{26}$. Proteins are the primary components of living organisms. The presence of higher protein levels in the plants increase food value or that a protein base bioactive compound could also be isolated in future ${ }^{27}$. Total protein content of $0.151 \pm 0.007$ $\mathrm{mg} / \mathrm{gdwt}$ is found in the leaves and $0.068 \pm 0.009 \mathrm{mg} / \mathrm{gdwt}$ in the bark of Cochlospermum religiosum. The quantitative estimation of total chlorophyll content found in leaves of Cochlospermum religiosum is $0.34 \pm 0.04 \mathrm{mg} / \mathrm{gdwt}$ and in bark is $0.14 \pm 0.04 \mathrm{mg} /$ gdwt. Chlorophyll is the most indispensable class of primary compounds as they are the only substances that capture sunlight and make it available to plant system for its cultivation of photosynthesis ${ }^{28}$ (Graph-1).

\section{Quantification of Secondary Metabolites}

The general assessment of the analytical results for different parts of Cochlospermum religiosum showed individual specificity of each studied parts and rich diverse spectrum of secondary metabolites differing from one another. The highest total flavonoid content was found in leaves $(0.077 \pm$ $0.04 \mathrm{mg} / \mathrm{gdwt})$ followed by bark $(0.052 \pm 0.002 \mathrm{mg} / \mathrm{gdwt})$ (Table 1 and Graph-1). Similar results were recorded from Urtica dioica and Equisetum maximum ${ }^{29}$. Flavonoids are plant secondary metabolites widely distributed in the plants and more than 6000 flavonoids have been identified in plants $^{30}$. Flavonoids are a group of poly phenolic compounds with known properties which include free radical scavenging inhibition of hydrolytic and oxidative enzymes and antiinflammatory action ${ }^{31}$. These are vital in combating the free radicals which damage human cells ${ }^{32}$. Numerous epidemiological studies confirm significant relationship between the high dietary intake of flavonoids and the reduction of cardiovascular and carcinogenic risk $^{33}$. There have been an increasing number of reports that directly contradict the putative role of flavonoids as antioxidant and anti-cancer agents ${ }^{34}$. The highest total phenolic content was found in bark $(1.5 \pm 0.002 \mathrm{mg} / \mathrm{gdwt})$ followed by leaf (1.29 $\pm 0.045 \mathrm{mg} / \mathrm{gdwt}$ ). Similar results were reported from Mellilotus officinalis ${ }^{29}$. A number of data showed that the presence of phenolics in food is particularly important for their oxidative stability and antimicrobial protection ${ }^{35}$. Phenols are ubiquitous secondary metabolites in plants and comprise a large group of biologically active ingredients. Around 8000 compounds of phenols have been identified so far in plants ${ }^{36}$. These phenolic compounds possess a wide spectrum of biochemical activities such as antioxidant, antimutagenic, anticarcinogenic as well as ability to modify the gene expression ${ }^{37}$. The highest total tannins content was found in bark $(0.034 \pm 0.002 \mathrm{mg} / \mathrm{gdwt})$, followed by leaf $(0.026 \pm 0.03 \mathrm{mg} / \mathrm{gdwt})$. Tannins are widely distributed in almost all plant foods ${ }^{38}$. The tannin containing remedies are used as antihelminthic ${ }^{39}$, antioxidants, antimicrobial and antiviral $^{40}$. The highest total alkaloids content was found in leaf $(0.3 \pm 0.011 \mathrm{mg} / \mathrm{gdwt})$ followed by bark $(0.04 \pm 0.00 \mathrm{mg} /$ gdwt).

Table 1: Quantitative Analysis of Phytochemical Constituents from Leaves and Stem Bark of Cochlospermum religiosum

\begin{tabular}{|c|c|c|}
\hline \multirow{2}{*}{$\begin{array}{c}\text { Phytochemical } \\
\text { Name }\end{array}$} & \multicolumn{2}{|c|}{ Cochlospermum religiosum } \\
\cline { 2 - 3 } & Leaf (mg / gdwt) & Stem bark (mg / gdwt) \\
\hline Proteins & $0.151 \pm 0.007$ & $0.068 \pm 0.009$ \\
\hline Chlorophylls & $0.34 \pm 0.04$ & $0.14 \pm 0.04$ \\
\hline Lipids & $0.200 \pm 0.057$ & $0.040 \pm 0.000$ \\
\hline Carbohydrates & $0.075 \pm 0.030$ & $0.110 \pm 0.020$ \\
\hline Phenols & $1.290 \pm 0.045$ & $1.500 \pm 0.002$ \\
\hline Tannins & $0.026 \pm 0.030$ & $0.034 \pm 0.002$ \\
\hline Flavonoids & $0.077 \pm 0.040$ & $0.052 \pm 0.002$ \\
\hline Alkaloids & $0.300 \pm 0.011$ & $0.040 \pm 0.000$ \\
\hline
\end{tabular}

Note: ' \pm ' indicates standard error

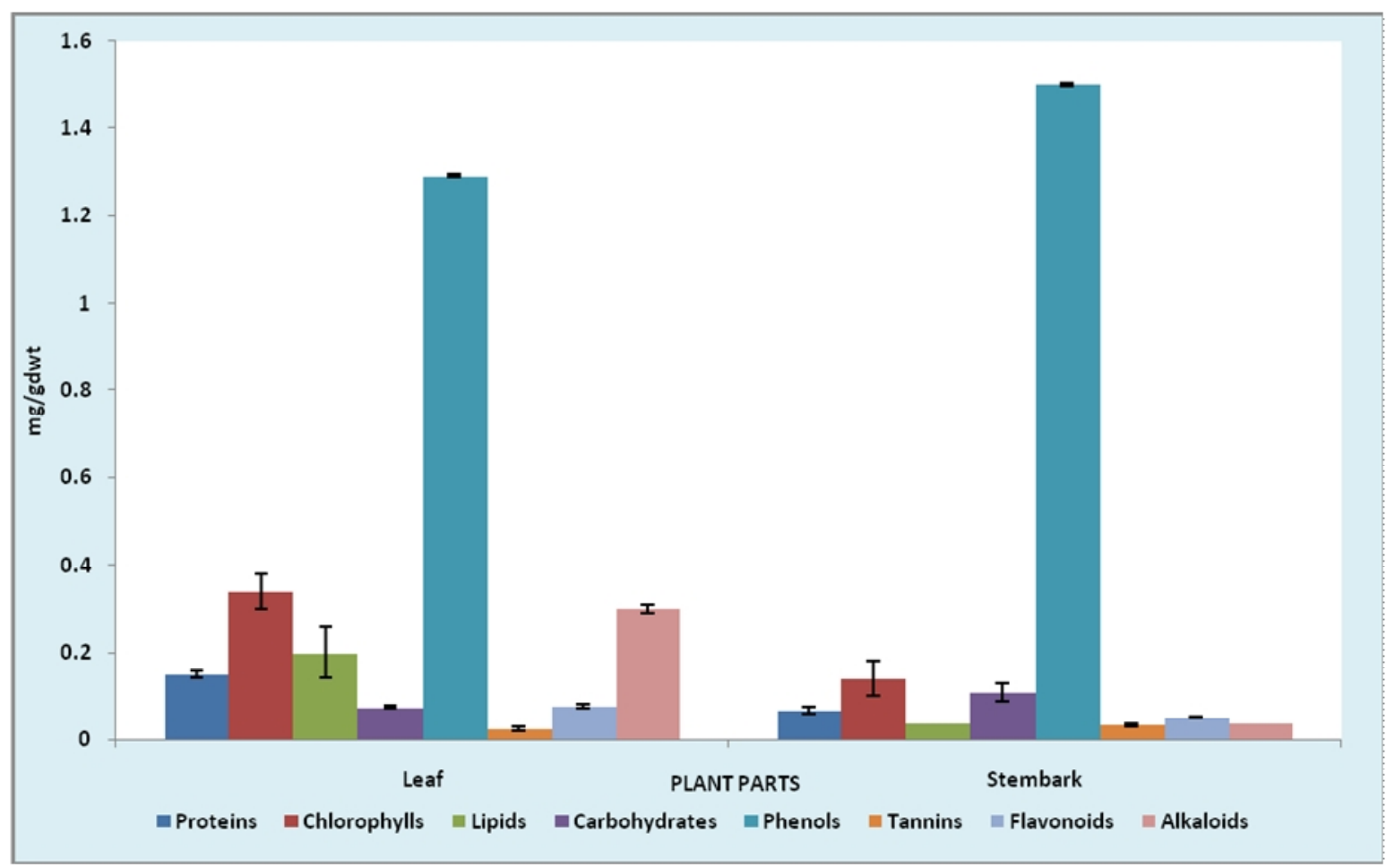

Graph 1: Quantitative Analysis of Phytochemical Constituents from Leaves and Stem Bark of Cochlospermum religiosum 
The alkalaoids are one of the most diverse groups of secondary metabolites found in living organisms and have an array of structure types, biosynthetic pathways, and pharmacological activities. Anti-diarrhoeal activity of Piperine, the principal alkaloids of Piper longum and Piper nigrum, was investigated against diarrhoea ${ }^{41}$, imidazole alkaloid, chaksine isolated from Cassia abtusa has antibacterial activity ${ }^{42}$ and leaf extract of Ricinus cummunis was evaluated for hepato protective choleretic and anticholestatic activity ${ }^{43}$. Total alkaloids of Eclipta alba have been reported have significant analgesia used ${ }^{44}$. Based on the results chlorophylls and phenolic compounds are highest in leaves and stembark of Cochlospermum religiosum, followed by other primary and secondary metabolites.

\section{CONCLUSION}

In the present study, Cochlospermum religiosum contains many primary and secondary metabolites like proteins, lipids, starch, sugar, phenols, alkaloids, flavonoids, tannins and steroids. Highest amount of phenols of secondary metabolites were found to be rich in leaves and bark of Cochlospermum religiosum. These results are suggestive of primary and secondary bioactive compounds are commercially and pharmaceutically important. Analysis of plants primary metabolites is necessary for knowing the nutritional potential and secondary metabolites for medicinal value.

\section{REFERENCES}

1. Goud PS, Murthy KS, Pullaiah T, Babu GV. Screening for antibacterial and antifungal activity of some medicinal plants of Nallamalais-Andhra Pradesh, India. J Econo Taxono Bot 2005; 29: 704-08.

2. Cecilie SN, Drissa D, Kari I, Terje EM, Tsukasa M, Hiroaki K. Medicinal use of Cochlospermum tinctorium in Mali Anti-ulcer, radical scavenging and immunomodulating activities of polymers in the aqueous extract of the roots. J Ethnopharmacol 2005; 255-269.

3. Sasikala A, Savithramma N. Biological synthesis of silver nanoparticles from Cochlospermum Religiosum and their antibacterial efficacy. J Pharm Sci Res 2012; 4: 1836-1839.

4. Sasikala A, Savithramma N. Phytochemical diversity of Cochlospermum religiosum (L.) Alsten - A medicinal tree species. Threats and Concerns to Biodiversity edited by N Savithramma; 2012. p. 50-59.

5. Vijayavergia R, Kumar J. Quantification of primary metabolites of Nerium indicum Mill. Asian J Experim Sci 2007; 21: 123-128.

6. Rishi A and Sarin R. Estimation of primary metabolites from Gloriosa superba L. in vivo and in vitro. Int J Mendel 2009; 26: 87.

7. Vijayavergia R, Sharma S, Sing T. Biochemical estimation of primary metabolites of some medicinal plants of Euphorbiaceae family. J Indian Bot Soc 2009; 88: 116-119.

8. Sagwan S, Rao DV, Sharma RA. Biochemical estimation of primary metabolites from Pongamia pinnata (L.): An important biodiesel plant. Int J Pharma Sci Rev Res 2010; 5: 146-149.

9. Talreja T. Biochemical estimation of three primary metabolites from medicinally important plant Moringa oleifera. Int J Pharma Sci Rev Res 2011; 7: 186-188.

10. Akindele AJ, Adeyemi OO. Anti inflammatory activity of the aqueous leaf extract of Byrsocarpus coccineus. Fitoterapia 2007; 78: 25-28. http://dx.doi.org/10.1016/j.fitote.2006.09.002 PMid:17118572

11. Linga Rao M, Savithramma N. Quantification of Primary and Secondary Metabolites of Svensonia hyderobadensis - A Rare Medicinal Plant. Int J Pharm Pharma Sci 2012; 4(1): 519-521.

12. Savithramma N, Bhumi G. Quantitative estimation of Biochemical compounds of Boswellia ovalifoliolata Bal. and Henry- An endemic, endangered and globally threatened medicinal tree taxa of Seshachalam hill range of Eastern Ghats of India. J Pharm Res 2011; 4: 4694-4695.

13. Ankanna S, Savithramma N. Quantitative analysis of some secondary metabolites of Shorea tumbuggaia Roxb. - an endemic, endangered and globally threatened medicinal tree species. J Pharm Res 2011; 4(10): 3582-3584.

14. Nwokocha A, Blessing IO, Agabagwa, Okoli BE. Comparative phytochemical screening of Jatropha L. Species in the Niger Delta. Res J Phytochem 2011; 5: 107-114. http://dx.doi.org/10.3923 /rjphyto.2011.107.114
15. Majaw S, Moirangthem J. Qualitative and quantitative analysis of Clerodendron colebrookianum Walp. Leaves and Zingiber cassumunar Roxb. Rhizomes, Ethnobot leaf 2009; 13: 578-89.

16. Njoku PC and Akumefula MI, Phytochemical and nutrient evaluation of Spondias mombin leaves. Pak J Nutri 2007; 6: 613-615. http://dx.doi. org/10.3923/pjn.2007.613.615

17. Lowry OH, Rosebrough NJ, Farr AL, Randall RJ. Protein measurement with the Folin phenol reagent. J Biol Chem 1951; 193: 265-275. PMid: 14907713

18. Dubois M, Gills KA, Hamilton JK, Rebers PA, Smith F. Colorimetric method for determination of sugar and related substances. Anal Chem 1956; 28: 350-351. http://dx.doi.org/10.1021/ac60111a017

19. Jayaraman J. Laboratory manual in biochemistry. Wilsey Eastern Limited, New Delhi; 1981. p. 96-97.

20. Holden M. Chlorophylls, In chemistry and biochemistry of plant pigments. Goodwin. T.W. (Ed.) Academic Press. London; 1960. p. 462488.

21. Makkar HPS, Blummel M, Borowy NK, Becker K. Gravimetric determination of tannins and their correlations with chemical and protein precipitation methods. J Sci Food Agri 1993; 61: 161-165. http:// dx.doi.org/10.1002/jsfa.2740610205

22. Boham BA, Kocipal Abyazan R. Flavonoids and condensed tannins from leaves of Hawaiian vaccinium vaticulatum and V. Calycinum. Pacific Sci 1974; 48: 458-463.

23. Harborne JB. Methods in Plant Biochemistry, Vol.1 Plant Phenolics, Dey PM and Harborne JB (Eds.), Academic Press, London; 1989. p. 1.

24. Yadav PR, Tyagi R. Lipid Biotechnology, 1 Discovery Publishing House - New Delhi; 2006. p. 89.

25. Garth E, Sheila B, Elaine B, Kerr W. Economics of starch production in the $20 ; 1998$.

26. Freeze H. Disorders in protein glycosylation and protein therapy. J Pediatrics 1998; 133: 553-600. http://dx.doi.org/10.1016/S00223476(98)70096-4

27. Thomson S, Handen HS, Nymn V. Ribosome inhibiting proteins from in vitro cultures of Phytolacca decandra. Planta Medica 1991; 57: 232236. http://dx.doi.org/10.1055/s-2006-960080 PMid:1896521

28. Murray AP, Gibbs CF, Longmore AR. Determination of chlorophyll in marine waters: Inter comparison of a rapid HPLC method with full HPLC, Spectrophotometric and fluorometric methods. Mari Chem 1986; 19: 211-227. http://dx.doi.org/10.1016/0304-4203(86)90024-1

29. Pourmorad F, Hosseinimehr SJ and Shahabimajd N. Antioxidant activity, phenol and flavonoid contents of some selected Iranian medicinal plants. Afri J Biotech 2006; 5: 1142-1145.

30. Harborne JB, Williams CA. Advance in flavonoid research since 1992. Phytochemistry 2000; 55: 481-504. http://dx.doi.org/10.1016/S00319422(00)00235-1

31. Frankel E. Nutritional benefits of flavonoids. International conference on food factors: Chemistry and Cancer Prevention, Hamamatsu, Japan. Abstracts 1995; 6: 2 .

32. Ozyurt D, Ozturk BD, Apak R. Determination of total flavonoid content of Urtica dioica L. by a new method. Adnan Menderes University, $4^{\text {th }}$ AACD Congress, Turkey, Proceedings book; 2004.

33. Cook NC, Samman S. Flavonoids-chemistry, metabolism, cardioprotective effects and dietary sources. Nutri Biochem 1996; 7 : 66- 76. http://dx.doi.org/10.1016/0955-2863(95)00168-9

34. Hodnick WF, Ahmad S, Pardini RS. Introduction of oxidative stress by redox active flavonoids. Adv Experi Med Biol 1998; 439: 131-150. http://dx.doi.org/10.1007/978-1-4615-5335-9_10

35. Floridi S, Montanari L, Ombretta M, Fantozzi P. Determination of free phenolic acids in wort and beer by colorimetric array detection. J Agric Food Chem 2003; 51: 1548-1554. http://dx.doi.org/10.1021/jf0260040 PMid: 12617582

36. Marinova D, Ribarova F, Atanassova M. Total phenolics and total flavonoids in Bulgarian fruits and vegetables. J Univ Chem Tech Metallurgy 2005; 40: 255-260.

37. Nakamura Y, Watanabe S, Miyake N, Kohno H, Osawa T. Evaluation as novel radical scavenging antioxidants. J Agric Food Chem 2003; 51: 3309-3312. http://dx.doi.org/10.1021/jf0341060 PMid:12744659

38. Serrano J, Puupponen Pimia R, Dauer A, Aura AM, Saura Calixto F. Tannins: Current knowledge of food sources, intake, bioavailability and biological effects. Mol Nutr Food Res 2009; 53: 310-329. http:// dx.doi.org/10.1002/mnfr.200900039 PMid:19437486

39. Ketzis JK, Vercruysse J, Stromberg BE, Larsen M, Athanasiadou S, Houdijk JG. Evaluation of efficacy expectations for novel and nonchemical helminth control strategies in ruminants. Vet Parasitol 2006; 139: 321-335. $\quad$ http://dx.doi.org/10.1016/j.vetpar.2006.04.022 PMid: 16769174

40. Buzzini P, Arapitsas P, Goretti M, Branda E, Turchetti B, Pinelli P, Ieri F, Romani A. Antimicrobial and antiviral activity of hydrolysable tannins. Mini Rev Med Chem 2008; 8: 1179-1187. http://dx.doi.org/10.2174/138955708786140990 PMid:18855732 
41. Bajad S, Bedi KL, Singla AK, Johri RK. Anti diarrheal activity of Piperine in mice. Planta medica 2001; 67: 284-287. http://dx. doi.org/10.1055/s-2001-11999 PMid:11345706

42. Gupta KC, Chopra IC. A short note on antibacterial properties of chaksine, an alkaloide from Cassia abus Linn. Indian J Med Res 1953; 41: 459-460. PMid: 13142674

43. Visen B, Shukla G, Patnaik S, Tripathi D, Kulshreshtah R, Dhawan B. Hepatoprotective activity of Ricinus communis leaves. Int J Pharmacog 1992; 30: 241-250. http://dx.doi.org/10.3109/13880209209054007
44. Sawant M, Issac JC, Narayanan S. Analgesic studies on total alkaloids and alcohol extract of Eclipta alba (Linn) Hassk. Phytother Res 1997; 18: 111-113. http://dx.doi.org/10.1002/ptr.1165 PMid:15022160

Cite this article as:

Sasikala A, Linga Rao M and Savithramma N. Quantification of primary and secondary metabolites from leaves and stem bark of Cochlospermum religiosum (L) Alston. Int. Res. J. Pharm. 2013; 4(8):228-231 http://dx.doi. org/10.7897/2230-8407.04845

Source of support: Nil, Conflict of interest: None Declared 